\title{
The Detection of Starvation-specific Antigens in Two Marine Bacteria
}

\author{
By NAN H. ALBERTSON, ${ }^{1}$ GARTH W. JONES ${ }^{2}$ AND \\ STAFFAN K JELLEBERG ${ }^{1 *}$ \\ ${ }^{1}$ Department of Marine Microbiology, University of Göteborg, Carl Skottsbergs Gata 22, \\ S-413 19 Göteborg, Sweden \\ 'Department of Microbiology and Immunology, 6723-0620 Medical Science Building, \\ University of Michigan, Ann Arbor, Michigan 48109, USA
}

(Received 2 February 1987; revised 30 March 1987)

\begin{abstract}
Antisera produced against starved cells of two marine bacteria (a Vibrio sp. and an unidentified Gram-negative motile rod) were titrated in order to quantify with respect to time of starvation the appearance of starvation-specific antigens. Polyacrylamide gels of lipopolysaccharide digests, and of total protein and membrane and periplasmic fractions, were prepared, blotted and immunoassayed to determine the location(s) of the antigenic response. For the Vibrio isolate, no starvation-specific antigens were detected, but such antigens were detected for the other isolate; they were proteinaceous and were located in the outer membrane and periplasmic space. Titrations of whole cells indicated that the antigenic change in the cell surface occurred in the initial phase of starvation and increased during the first $14 \mathrm{~h}$ of the starvation period studied.
\end{abstract}

\section{INTRODUCTION}

It is of prime importance to characterize specifically the survival traits of marine as well as other starved and non-growing bacteria. An understanding of these mechanisms is highly significant in areas such as ecology, public health and risk assessment of released bacteria. Some of the survival mechanisms of marine bacteria have been characterized (Dawson et al., 1981; Amy et al., 1983; Kjelleberg et al., 1983) and the results support the notion that the starvation survival response is a collection of active processes. The aim of this study was to use antibodies specific for starved cells to determine the nature, location and time of expression of starvation antigens. The ultimate goal is to disclose the regulatory control of the starvation survival pathway.

The starvation response of the two copiotrophic marine bacteria used in this study has been characterized (Dawson et al., 1981; Kjelleberg \& Hermansson, 1984; Mårdén et al., 1985). The marine Vibrio sp. DW1 and the unidentified isolate S14 share some starvation-induced characteristics such as changes in cell number, size, and endogenous metabolism. Changes in hydrophobicity, degree of adhesion to inanimate surfaces, protein composition (as seen by twodimensional gel electrophoresis) and rate of protein synthesis have also been examined. Cells of DW1 become more hydrophobic and display an increase in the degree of irreversible binding with time of starvation (Dawson et al., 1981; Kjelleberg \& Hermansson, 1984), whereas these changes in S14 cells are less pronounced. Silver-stained two-dimensional gels of whole-cell extracts have been examined for both organisms in growth and after starvation (Jouper-Jaan et al., 1986). Dynamic starvation-induced protein rearrangements occur in both organisms as evidenced by the disappearance of certain protein spots, along with the production of new ones, during starvation. An increase in protein synthesis was observed during the first few hours of starvation prior to a decreased but ongoing synthesis throughout a starvation period of $120 \mathrm{~h}$ (Nyström et al., 1986). The results observed for these marine bacteria encouraged us to use the immune response as a complement to the previous experiments. The advantage of the immune response to whole starved cells is that the immune system recognizes the actual surface and 
cellular components presented to it. When analysed, the polyvalent antibody-antigen reaction allows detailed observations of the changes that occur during starvation and which are specific for starved cells.

\section{METHODS}

Bacterial strains, cultivation and starvation conditions. The two marine isolates used in this study were a Vibrio sp. strain DW1, characterized by Dawson et al. (1981), and S14, an unidentified Gram-negative motile rod described by Humphrey et al. (1983) and Mårdén et al. (1985). DW1 was grown on Lewin's medium (Lewin \& Lounsbery, 1969) and S14 on a modification of the V-medium for marine bacteria of Väätänen (1976). A nine-salt solution (NSS) (Mårdén et al., 1985) was used for washing the bacteria and in the starvation regimes. Cells were grown at $26^{\circ} \mathrm{C}$ to exponential growth, harvested by centrifugation $\left(8000 \mathrm{~g}\right.$ for $6 \mathrm{~min}$ at $\left.4^{\circ} \mathrm{C}\right)$ washed twice in NSS and suspended in NSS to give approximately $5 \times 10^{7}$ bacteria $\mathrm{ml}^{-1}$ in the starvation regimes. The cells remain viable (determined by c.f.u.) during the starvation period studied (Mårdén et al., 1985).

Preparation of antisera. After $24 \mathrm{~h}$ starvation in NSS, the bacterial suspension was centrifuged as described and resuspended in NSS to give a density of $2 \times 10^{9}$ bacteria $\mathrm{ml}^{-1} ; 1 \mathrm{ml}$ of this suspension was used for injections. Antibodies were produced in female rabbits $(2-3 \mathrm{~kg})$, one for each organism. Injections were made intravenously into the marginal ear vein every $5 \mathrm{~d}$ over a period of 6 weeks and the animals were bled $5 \mathrm{~d}$ after the last injection. Subsequent to this, booster injections and repeated bleedings were undertaken. The serum was obtained by centrifugation of the clotted blood. The titre of the serum against starved DW1 or S14 cells was constant throughout the sampling period.

Absorption and titration of antisera. In order to enrich the crude antiserum for antibodies specific for starved cells, an absorption procedure with growing cells was followed. Exponential-phase cells washed in NSS were centrifuged and an appropriate volume of the antiserum was added to the pellet to give $10^{10}$ cells (ml antiserum) ${ }^{-1}$. This mixture was incubated at $37^{\circ} \mathrm{C}$ for $1 \mathrm{~h}$, then at $4{ }^{\circ} \mathrm{C}$ overnight. After centrifugation the supernate was stored at $-20^{\circ} \mathrm{C}$ until use. Titrations were carried out in 96-well microtitre plates (Nunc, round-bottomed, $250 \mu \mathrm{l}$ capacity). Twofold serial dilutions were prepared in duplicate, resulting in antiserum dilutions ranging from 2 to 2048. The microtitre plate was incubated at $37^{\circ} \mathrm{C}$ for $1 \mathrm{~h}$ then at $4{ }^{\circ} \mathrm{C}$ overnight. The optimal ratio for agglutination was determined by the shape of the bacterial precipitate.

Lipopolysaccharide (LPS) analysis. To determine if the antigenic change occurring in strain S14 depended on changes in LPS, a preliminary characterization of this molecule was undertaken. The LPS of growing or starved (24 h) S14 cells was extracted according to Hitchcock \& Brown (1983) and digested with Proteinase K (Serva Feinbiochemica). The lysate was separated electrophoretically in gradient $(7.5-15 \%$, w/v) polyacrylamide gels with the Laemmli buffer system (Laemmli, 1970) at $30 \mathrm{~mA}$ for $4 \mathrm{~h}$. The gels were stained with silver (Tsai \& Frasch, 1982).

Preparation of membrane and periplasmic fractions. Outer membrane and cell membrane fractions of strain S14 starved for $24 \mathrm{~h}$ were prepared (Achtman et al., 1983). Periplasmic proteins were obtained by osmotic shock in double-distilled water as follows. A $24 \mathrm{~h}$ starvation suspension $(120 \mathrm{ml})$ was centrifuged and resuspended in $1 \mathrm{ml}$ double-distilled water for $20 \mathrm{~min}$. After centrifugation, the supernate was filtered (Millipore, $0.22 \mu \mathrm{m}$ ) solubilized (as described below) and stored at $-20^{\circ} \mathrm{C}$ until use.

$S D S-P A G E$. Proteins were extracted and denatured by boiling for $3 \mathrm{~min}$ in a solubilizing buffer containing $2 \%$ (w/v) SDS, $5 \%(\mathrm{v} / \mathrm{v}) 2$-mercaptoethanol, $10 \%(\mathrm{w} / \mathrm{v})$ sucrose and $0.002 \%$ bromophenol blue in $0.0625 \mathrm{M}$-Tris/ $\mathrm{HCl}$ (pH 6.8) and samples were kept at $-20{ }^{\circ} \mathrm{C}$ until use. The protein preparations were subjected to discontinuous SDS-PAGE with the Laemmli buffer system (Laemmli, 1970). The $3 \%$ stacking gel and the $15-25 \%$ gradient separating gel contained $0.125 \%$ SDS. Electrophoresis was carried out at $30 \mathrm{~mA}$ for $5 \mathrm{~h}$. Approximately $15 \mu \mathrm{g}$ protein was added to each well. The gels were stained with silver using the modification of Mose-Larsen et al. (1983) of the method of Ansorge (1983).

Immunoblotting and antigen detection. The separated proteins and LPS digests were transferred electrophoretically (Bio-Rad Trans-Blot cell) onto nitrocellulose paper or modified Nylon-66 membranes (Gelman Sciences) in a $25 \mathrm{~mm}$-Tris, $192 \mathrm{~mm}$-glycine buffer containing $20 \%(\mathrm{v} / \mathrm{v})$ methanol (pH 8.3) at $30 \mathrm{~V}$ overnight. Primary antiserum was diluted $1: 1200$ and specific antigens were detected using goat anti-rabbit horseradish peroxidase conjugated antibodies (Bio-Rad Immuno-Blot Assay Kit), according to the manufacturer's instructions.

\section{RESULTS}

\section{Titrations of the antisera}

To determine at what time and to what degree the starvation antigens appeared, a series of starved cell suspensions (starvation times ranged from 0 to $24 \mathrm{~h}$ ) were titrated against the absorbed antisera (Fig. 1). Washed S14 cells, harvested in the exponential growth phase, 


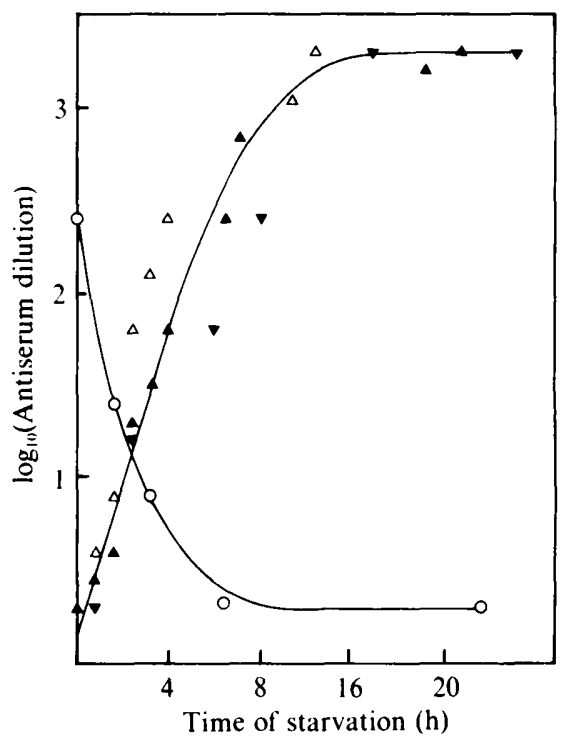

Fig. 1. Titrations of whole cells with homologous rabbit antibodies against whole starved ( $24 \mathrm{~h}$ in NSS) cells of strains DW1 (O, representative of a typical experiment: three experiments were performed) and S14 (triangles, representing three separate experiments). Titrations were carried out in duplicate.

produced starvation antigens after less than $1 \mathrm{~h}$ in the starvation regime. The titre increased during the first few hours and reached a plateau after $14 \mathrm{~h}$ of starvation. The titre against DW 1 cells decreased with time of starvation, reaching a minimum after $4 \mathrm{~h}$. Titrations were also carried out against washed S14 cells in the early and late stationary phase (after 5 and $24 \mathrm{~h}$ of growth respectively). No antigen-antibody reaction was detected (data not shown). All titrations were repeated a minimum of three times.

\section{LPS analysis}

Based on the results of the titrations against starved cells of S14, the possible role of changes in the LPS molecules in the development of starvation-specific antigens was investigated. No obvious differences were detected in the electrophoresis patterns of LPS digests from growing and starved cells (results not shown). These were determined a minimum of three times with varying amounts of LPS extract, to achieve good resolution throughout the separation pattern. The same result was obtained by blotting gels with LPS extracts followed by an immunoassay (data not shown). No antibody-antigen reaction was detected. Confirmation that LPS extracts could be transferred and blotted in the same manner as proteins was provided by the antibodyantigen reaction detected in blotted LPS extracts of strain DW1 (data not shown).

\section{SDS-PAGE of total-cell, outer-membrane, cell-membrane and periplasmic proteins}

Total protein digests of growing and starved cells of strains DWl and S14 (Fig. 2) were separated electrophoretically (Fig. $2 a, c$ ), then transferred and immunoassayed (Fig. $2 b, d$ ). No starvation-specific antigens were detected for DW 1 ; the immunoassays on growing and starved cells gave identical results. Several starvation-specific antigens were detected for S14, however. One small (14 kDa) and several larger (100-200 kDa) proteins were detected in the starved S14 cells. To determine the location of these antigens, starved $(24 \mathrm{~h}) \mathrm{S} 14$ cells were fractionated and analysed as previously described (Fig. 3). This procedure demonstrated that the smaller protein found in the whole-cell digests was located in the outer membrane, and that the larger protein bands corresponded to periplasmic proteins.

All of the above results are representative of a minimum of three separate experiments. 
(a)

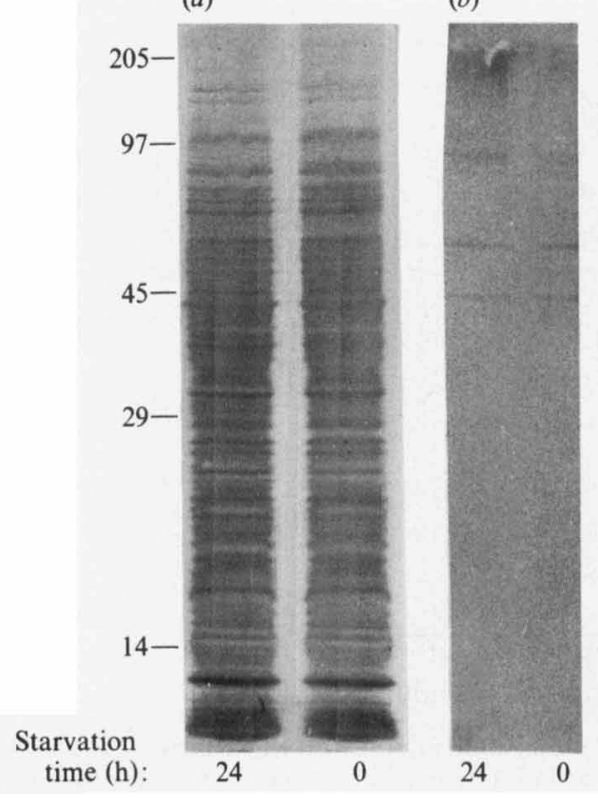

(c)

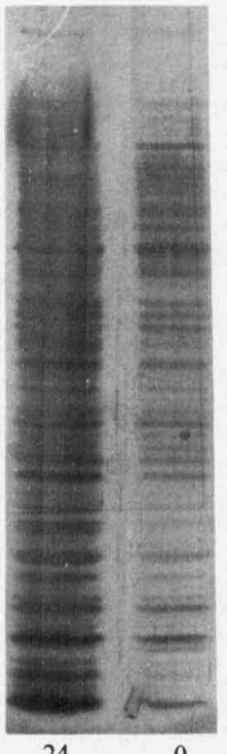

(d)

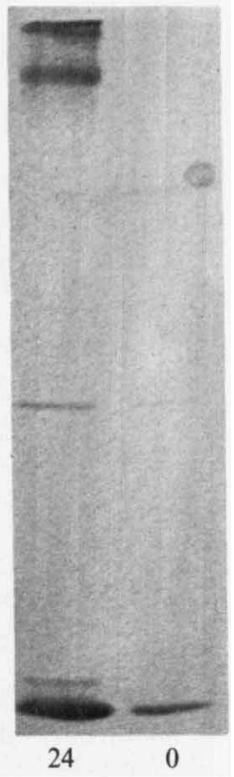

Fig. 2. Immunological analysis of starvation-specific antigens of strains DW $1(a, b)$ and $\mathrm{S} 14(c, d)$. Proteins were separated in $15-25 \%$ gradient polyacrylamide gels containing SDS $(a, c)$, then transferred and immunoblotted with rabbit antibodies to whole starved cells and detected by anti-rabbit horseradish peroxidase conjugated antibodies $(b, d)$. Molecular masses of proteins in the reference standard are indicated in $\mathrm{kDa}$.

(a)

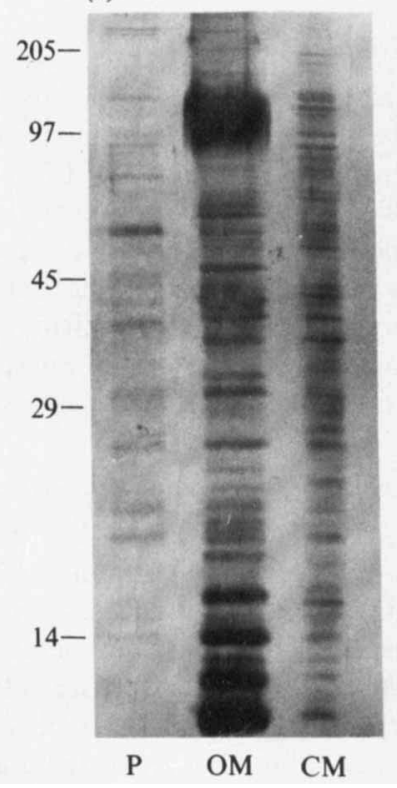

(b)

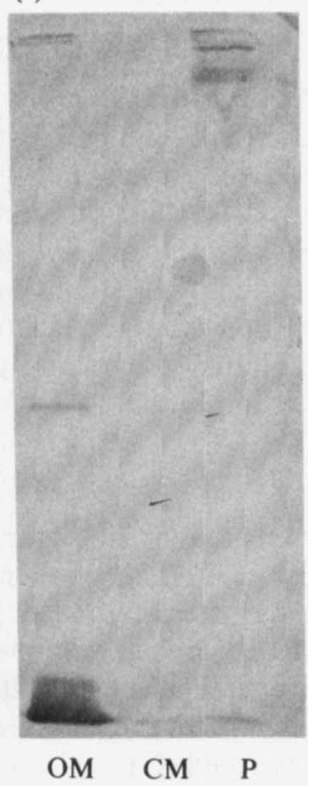

Fig. 3. Detection of starvation-specific proteins by electrophoresis ( $a$ ) followed by immunoblotting $(b)$ in outer-membrane $(\mathrm{OM})$, cell-membrane $(\mathrm{CM})$ and periplasmic $(\mathrm{P})$ fractions of $\mathrm{S} 14$ cells starved for $24 \mathrm{~h}$. Molecular masses of proteins in the reference standard are indicated in kDa. 


\section{DISCUSSION}

The production of antibodies against starved cells can be an effective tool in the attempts to elucidate the mechanisms responsible for the starvation survival response.

Changes induced in the cell surface of strain DW1 by starvation have been described previously (Dawson et al., 1981). The changes in surface-related characteristics such as hydrophobicity and adhesion (Kjelleberg \& Hermansson, 1984) indicate that the surface of DW 1 is altered antigenically upon starvation. The methodology employed in this study did not, however, reveal such changes, as no starvation-specific antigens were found. The decrease in the antiserum titre with starvation time implies that growing and starved cells expose the same antigens, but that starved cells reveal fewer of them. Protein degradation is important in the survival of starving cells (Cozzone, 1981; Reeve et al., 1984a), in order to provide amino acids for protein synthesis (Reeve et al., 1984b). Strain DW1 may preferentially degrade surface proteins to provide amino acids for the synthesis of other starvation proteins.

When subjected to a starvation regime, exponential-phase cells of strain S14 rapidly responded by producing or revealing new proteinaceous antigens at the cell surface. This is in agreement with two-dimensional electrophoresis studies (Jouper-Jaan et al., 1986) which showed the appearance of at least two new protein spots after $24 \mathrm{~h}$ of starvation. This response is not restricted to starving marine bacteria (Amy \& Morita, 1983). New or increased synthesis of at least 30 polypeptides in the initial phase of carbon starvation of Escherichia coli has been demonstrated (Groat \& Matin, 1986). Since 8 of 10 proteins in ethanol-shocked cells were also synthesized in carbon-starved $E$. coli, it can be envisaged that this starvation triggers a stress response in E. coli. A less extensive overlap was found in Salmonella typhimurium, where 2 of 11 carbon-limitation-induced proteins were also synthesized by cells exposed to heat shock (Spector et al., 1986). Similar comparisons of starvation- and heat- or ethanol-induced proteins for S14 cells may reveal which proteins are starvation-specific and unrelated to other stress conditions. The results in this paper suggest that a combination of methods such as twodimensional electrophoresis and immunoassays should be used to elucidate these mechanisms. It is worth emphasizing that slowly growing cells of a stationary-phase batch culture are physiologically unlike those subjected to a starvation regime, as determined by the antibodyantigen reaction. The starved viable but non-culturable cells of enteric pathogens (viviforms) found in marine waters are also suggested to be physiologically different from their growing counterparts (Grimes et al., 1986).

We also attempted to characterize the nature and location of the antigenic changes in strain S14. The antigenicity of the LPS molecule is well known and is employed in the identification of serotypes. PAGE and immunoassay procedures showed that the antigenic response in S14 did not depend on changes in LPS. The constancy of LPS in starvation conditions was also recognized by Xu et al. (1982), who used fluorescent antibodies against the LPS of $V$. cholerae to detect these organisms in the viviform stage. The phenomenon of viable but non-culturable pathogens has developed from the discrepancy in total counts as measured by traditional bacteriological culture techniques and immunofluorescent microscopy. While the number of c.f.u. drastically decreases with time in seawater, the number of cells seen by the immunofluorescent method (which uses antibodies specific for the LPS of $V$. cholerae) does not, indicating that although $V$. cholerae undergoes major morphological and physiological changes upon starvation, the LPS remains fundamentally the same.

Examination of the proteins of strain S14 by SDS-PAGE and immunoblotting showed that one outer-membrane protein and several periplasmic proteins were responsible for the change in antigenicity of starved cells. Similar results have been reported for Klebsiella (Sterkenberg et al., 1984), where large amounts of a new $48 \mathrm{kDa}$ protein were found in the outer membrane of cells starved for glucose. These proteins may play a role in the effective scavenging ability of lowmolecular-mass compounds by starved cells (e.g. Morita, 1985). Preliminary pulse-labelling studies in vivo have revealed that these starvation-specific antigens of $\mathrm{S} 14$ cells are not products of degradation (T. Nyström, N. H. Albertson \& S. Kjelleberg, unpublished results). The production of antibodies against periplasmic proteins is probably a result of cell lysis, which 
would reveal underlying structures. The importance of amino-acid-binding proteins in the starvation survival response of strain S14 is evidenced by the fact that when starving cells are osmotically shocked, the cells will resynthesize these proteins while in the starvation regime (P. Mårdén, T. Nyström \& S. Kjelleberg, unpublished). Future work to elucidate the starvation survival pathway will focus on characterizing the function of the proteins required in starvation, which will permit identification of regulatory pathways of the starvation process.

This study was supported by a grant from the Swedish Natural Science Research Council.

\section{REFERENCES}

Achtman, M., Mercer, A., Kusecek, B., Pohl, A., HeUzenRoeder, M., AARONSON, W., SUTton, A. \& SILVER, R. P. (1983). Six widespread bacterial clones among Escherichia coli $\mathrm{K} 1$ isolates. Infection and Immunity 39, 315-335.

AMY, P. S. \& MORITA, R. Y. (1983). Protein patterns of growing and starved cells of a marine Vibrio sp. Applied and Environmental Microbiology 45, 17481752.

Amy, P. S., Pauling, C. \& Morita, R. Y. (1983). Starvation-survival processes of a marine Vibrio. Applied and Environmental Microbiology 45, 10411048.

ANSORGE, W. (1983). Fast visualization of protein bands by impregnation in potassium permanganate and silver nitrate. In Electrophoresis '82, pp. 235-242. Edited by D. Stathakos. Berlin \& New York: W. de Gruyter.

Cozzone, A. J. (1981). How do bacteria synthesize proteins during amino acid starvation? Trends in Biochemical Sciences 6, 108-110.

Dawson, M. P., Humphrey, B. A. \& Marshall, K. C. (1981). Adhesion: a tactic in the survival strategy of a marine Vibrio during starvation. Current Microbiology 6, 195-199.

Grimes, D. J., AtTwell, R. W., Brayton, P. R., Palmer, L. M., Rollins, D. M., Roszak, D. B., Singleton, F. L., Tamplin, M. L. \& Colwell, R. R. (1986). Fate of enteric pathogenic bacteria in estuarine and marine environments. Microbiological Sciences 3, 324-329.

Groat, R. G. \& Matin, A. (1986). Synthesis of unique proteins at the onset of carbon starvation in Escherichia coli. Journal of Industrial Microbiology 1, 69-73.

HitchCock, P. J. \& Brown, T. M. (1983). Morphological heterogeneity among Salmonella lipopolysaccharide chemotypes in silver-stained polyacrylamide gels. Journal of Bacteriology 154, 269-277.

HUMphrey, B., KJelleberg, S. \& Marshall, K. C. (1983). Responses of marine bacteria under starvation conditions at a solid-water interface. Applied and Environmental Microbiology 45, 43-47.

Jouper-JaAn, A., DahllöF, B. \& KJelleberg, S. (1986). Changes in the protein composition of three bacterial isolates from marine waters during short term energy and nutrient deprivation. Applied and Environmental Microbiology 52, 1419-1421.

KJelleberg, S. \& Hermansson, M. (1984). Starvationinduced effects on bacterial surface characteristics. Applied and Environmental Microbiology 48, 497-503.

KJelleberg, S., Humphrey, B. A. \& Marshall, K. C.
(1983). Initial phases of starvation and activity of bacteria at surfaces. Applied and Environmental Microbiology 46, 978-984.

LAEMMLI, U. K. (1970). Cleavage of structural proteins during the assembly of the head of bacteriophage T4. Nature, London 227, 680-685.

LEWIN, R. A. \& LouNSBERY, D. M. (1969). Isolation, cultivation and characteristics of flexibacteria. Journal of General Microbiology 58, 145-170.

márdén, P., Tunlid, A., Malmcrona-Friberg, K., Odham, G. \& Kuelleberg, S. (1985). Physiological and morphological changes during short term starvation of marine bacterial isolates. Archives of Microbiology 142, 326-332.

MORITA, R. Y. (1985). Starvation and miniaturisation of heterotrophs, with special emphasis on maintenance of the starved viable state. In Bacteria in Their Natural Environments, pp. 111-130. Edited by M. M. Fletcher \& G. D. Floodgate. London: Academic Press.

Mose-larsen, P., Fey, S., Bravo, R. \& Celis, O. (1983). Mouse mitochondrial protein IEF 24 : identification and immunohistochemical localization of mitochondria in various tissues. Electrophoresis 4, 247-256.

NYSTRÖM, T., MÅrdÉN, P. \& KJelleberg, S. (1986). Relative changes in incorporation rates of leucine and methionine during starvation survival of two bacteria isolated from marine waters. FEMS Microbiology Ecology 38, 285-292.

REEVE, C. A., AMY, P. S. \& MATIN, A. (1984a). Role of protein synthesis in the survival of carbon-starved Escherichia coli K12. Journal of Bacteriology 160, 1041-1046.

ReEve, C. A., Bockman, A. T. \& Matin, A. (1984b). Role of protein degradation in the survival of carbon-starved Escherichia coli and Salmonella typhimurium. Journal of Bacteriology 157, 758-763.

Spector, M. P., Aliabadi, Z., Gonzalez, T. \& FOSTER, J. W. (1986). Global control in Salmonella typhimurium: two-dimensional electrophoretic analysis of starvation-, anaerobiosis-, and heat shockinducible proteins. Journal of Bacteriology 168, 420424.

Sterkenberg, A., Vlegels, E. \& Wouters, J. T. M. (1984). Influence of nutrient limitation and growth rate on the outer membrane proteins of Klebsiella aerogenes NCTC 418. Journal of General Microbiology 130, 2347-2355.

Tsai, C.-M. \& Frasch, C. E. (1982). A sensitive silver stain for detecting lipopolysaccharides in polyacrylamide gels. Analytical Biochemistry 119, 115-119. 
VÄÄTÄNEN, P. (1976). Microbiological studies in coastal waters of the Northern Baltic Sea. 1. Distribution and abundance of bacteria and yeasts in the Tvärminne area. Scientific Reports, Walter and Andre de Nottbeck Foundation 1, 1-58.
Xu, H.-S., Roberts, N., Singleton, F. L., AtTwell, R. W., Grimes, D. J. \& ColWell, R. R. (1982). Survival and viability of non-culturable Escherichia coli and Vibrio cholerae in the estuarine and marine environment. Microbial Ecology 8, 313-323. 